\title{
CHALLENGING QUESTIONS IN ENVIRONMENTAL MONITORING OF GROUNDWATER QUALITY IN RURAL AREAS OF KYIV'S REGION
}

\author{
${ }^{1 *}$ Viktoriia Serdiuk, ${ }^{l}$ Viktor Maksin \\ ${ }^{1}$ National University of Life and Environmental Sciences of Ukraine, 03041, Kyiv, Ukraine \\ *Corresponding author: serdiukvi@ukr.net
}

\begin{abstract}
Water resources protection is the prioritized target all over the world. Of course, it is Ukraine's aim too. Environmental crisis grows stronger because of global warming. Monitoring of groundwater quality and water resources assessment requires immediate improvement and a framework for monitoring should be launched as soon as possible. After all, the delays observed 10-15 years ago have shown that humanity is unable to postpone the issue of environmental crisis until the emergence of slow solutions, either the availability of funds, or any other favorable moment. Environmental crisis has already begun on a large scale. So, regions of Ukraine, which were fully provided with water, have started to suffer from drought and hurricanes. Water wells in rural areas are running dry and in some places the water disappeared completely. Kyiv's region is not an exception. Also, it is one of the most populated regions in Ukraine.

Eco-friendly water supply to Ukrainian cities is permanently much talked-of topic in public settings. At the same time, matter of villages survival is suppressed. Taking into account disproportionate distribution of water resources between rural community and citizens, financial component becomes considerably important. Forasmuch as water is supplied for more financially reliable big-city residents for tens or even hundreds of kilometers from the location of a city. Therefore, the area that would have used these resources (most commonly it is rural area) is losing them. Approaches to solution of this problem should be overviewed and water monitoring should be actively started. Also causes of pollution of existing drinking water should be identified and removed. It is imperative to act in a goal-directed manner and to found a group of researchers and advance into action. Underground water massif should be examined as complex system (supersystem) of drinking water supply of population with the goal of improvement of current monitoring system. At the legal level there are all opportunities for implementation of the research of this system and first steps of state monitoring implementation has been done. Although it is not enough. As mathematically sound calculations show, value of this work operation and involvement
\end{abstract}


of human resources could not be higher than service fee of safe environment and investments into health of rural population.

Key words: environmental monitoring; groundwater; groundwater areas; groundwater bodies; forecast of groundwater resources; water extraction.

\section{Introduction}

Groundwater is a vital source of freshwater in both urban and rural regions of the world. However, its injudicious abstraction and rapidly increasing contamination are posing a severe threat for sustainable water supply worldwide.

The groundwater quality deteriorates during post-monsoon seasons compared to pre-monsoon seasons, which indicates an increased influx of contaminants from different industries, mining areas, waste disposal sites and agricultural fields during monsoon seasons. This finding calls for the strict enforcement of regulations for proper handling of effluents from various contamination sources in the study area. This approach can be used for effective monitoring and management of groundwater quality on a basin basis (Jha 2020).

Rational formation of the groundwater quality monitoring network is important in identifying environmental pollutants, preserving natural components of the environment and preventing negative impacts on them. Identifying potentially hazardous activities, such as oil production and oil refining, allows researchers to predict the area of negative impact (Li 2019). And also to study the impact of already identified hazardous objects, such as closed landfill, which may have a negative impact on the environment (Aleya 2019). It is necessary to take into account a number of factors: the term of waste storage, the type of landfill (operating or closed) and the annual seasonal cycle (Abiriga 2020).

Given that the relief of Kyiv region is classified mainly as hilly plain with a general slope to the Dnieper valley, when modeling the groundwater monitoring system, the hydrogeological functioning of flow regimes in mountainous areas was not taken into account (Lehmann 2019).

Without the construction of a groundwater monitoring system, it is impossible to establish the level of anthropogenic pressure (Preziosi 2019 and Hansen 2019) on individual rural settlements of Kyiv region and the region as a whole. Excessive use of fertilizers, especially nitrogen, is a major problem for rural areas, leading to pollution of both groundwater and surface water.In Italy, the National Environmental Protection Agency (ISPRA) publishes annual reports containing the results of monitoring programs for pesticides in surface and groundwater. These programs were established to accomplish the EU Directives addressing the quality of water resources (drinking water, groundwater and surface water) such as the Water Framework Directive or the Directive on the 
Sustainable Use of Pesticides. These data can be extremely helpful for risk management actions as they can provide indications where to implement mitigation measures at the territorial scale (Di Guardo 2020).

Creating a system for monitoring the quality of groundwater in rural areas of Kyiv region, will predict the occurrence of adverse effects on the environment and will manage risks to prevent them not only in Kyiv region but also in other regions of Ukraine and the country as a whole.

Geospatial interpolation of the contaminants identified poor sanitary practices of waste management, agrarian activities, and industrial pollution as the prominent sources of groundwater contamination (Ravindra 2019).

At the time of drinking water deficit, it is very important not only to use nature waters in rational way, but also to monitor existing drinking water sources. The aim of such manipulations is to identify and adjust the influence of anthropogenic factors on it.

Resolution of the Cabinet of Ministers of Ukraine № 758 “About the Statement of the Order of Implementation of the State Waters Monitoring" has been registered in 19th of Sep 2018. It contains an information about the main requirements of organization an implementation of the monitoring of state water, requirements to cooperation of central authorities in process of that monitoring and proving public authorities and local governments by the information for decisionmaking regarding to water circumstance.

The main target of state water monitoring is to assure collection, processing, storage, generalization and analysis of the information about water objects condition, forecasting its changes and development scientifically defined recommendations for decision making in context of usage, water protection and water resources recreation (Cabinet of the Ministry of Ukraine 2018).

At last years in Ukraine were made meaningful steps in water resources protection. But, unfortunately, there is still "opened" question about financing this course of research and about sufficient amount of high qualified stuff. Nevertheless entities, that are working according to permission for special water consumption, are obligated to make quarter/annual laboratory analysis of drinking water quality (it is critical to define water depth at water wells). Also, these subjects have to pay quarter rent and make annual reports based on prescribed form. Although enterprises often give incomplete and sometimes inaccurate information on reports because of unawareness or lack of high qualified personnel.

Previously mentioned resolution includes information that data reports (including state statistic reports) that is predicted by law could be used for indication of surface and groundwater massifs condition and also seawater condition. These data show us not enough full and objective information about groundwater massifs condition, so the government is not able to forestall and 
minimize negative influence on water resources in full measure. No matter that Ukraine has already transited on catchment-based approach of water resources management.

Integrated management in Ukraine was not available in state level, because water resources management had been regulated with administrative structure (that means rivers also have broads between regions and countries) till $1^{\text {st }}$ of Feb 2017. Decisions on environmental position and water bodies resource usage were made by local bodies of Government Agency of Water Resources independently.

Ukraine has been switched to watershed management since 2017. In accordance with this approach to management of water resources, the main unit of management is river basin area. Given concept presupposes the financial gearing, which guaranties direct relation between payments for water consumption and financing of preferential water-protective measures in the area of basin.

Plan of Management of the River Basin is the key document. It contains definition of what the river basin is and also there is instruction for accomplishment of environmental objectives in river usage. Procedure of Plan of Management of the River Basin elaboration is determined on the legislative level. It should comply to Water Framework Directive of EU (Water Framework Directive 2000/60/EC). By 2024,9 plans must be developed to manage the largest Ukrainian rivers.

In the realm of underground waters, there is somewhat different situation. Because entities (under the terms of permission for special water consumption or in case of receival of the conclusion on assessment of environmental impact and arrangement of after-project monitoring of plans implementation) should develop observation holes or even chain of observation holes. But it is ignored very often.

If we want the monitoring of water massifs to be effective and rational, there is a need of mathematically defend decision of this issue and usage of system approach.

The purpose of current research is to develop effective supersystem of drinking water supply at rural territories by defined priority factor - underground water quality.

Challenging issues:

- deficiency of opportunities of making wide monitoring of underground water because of insufficient quantity of qualified researchers;

- non-availability of optimal system (plan) of underground water monitoring at rural territories;

- insufficient funding for making the underground water monitoring;

- ignorance of the fulfillment of the conditions established in the documents of permissive nature issued to business entities by them. 


\section{Materials and Methods}

Supersystem of drinking water supply is the object of the research. It is implemented as "complex system".

Data recourse of groundwater quality monitoring of Kyiv's region is the subject of the research.

Scientific assignment of the research (or how to meet the goal of scientific research) is to maximize effectiveness of object by optimization of information recourse monitoring and to review accuracy of task solution.

Scientific findings:

- Method of evaluation of groundwater environmental security (creating maps of Kyiv's region);

- Method of research object improvement (implementation of results of scientific assignment solution) by removing the cause of drinking water pollution;

- Evaluation of functional and economic effect.

- Assignment - providing drinking water from groundwater resources.

- Effect - supply of needed amount of drinking water with satisfactory quality. That means drinking water have to be put in order to State Sanitary Regulations and Rules "2.2.4-171-10" named "Hygienic Requirements to Quality of Water Intended for Human Consumption" and should become environmentally safe.

- The way of formation - removal of pollution factors of existing sources and development of new drinking water sources (exploring areas with potential location of groundwater).

- Resource content (tools):

1) Special purpose (monitoring, purification of existing and development of new sources of drinking water supply).

2) General purpose (energy supply, material security, financial resources).

3) Data resource (establishment of regulatory database and situation data, establishing procedures for the information technology database, implementation of informational instruments storage of object management system).

- Structure - management of informational side (hierarchical system of managerial bodies) and executory (related to resources) side (making-up the multi-item forces (staff personnel) with sources for making an effect).

- Process - functioning of the object related to creation of chosen systematical effect by resource potential power.

- Management - organizational (plan of actions and problem definition for forces (personnel)) and operative (coordination of the process of system functioning). 
Formulas, that have been used for calculating of statistical expectation of research practice, have been adapted to tasks solution of underground water monitoring. Mathematical expectation was calculated to determine the number of investigated wells and the cost of labor costs. The calculation formulas include values such as: the number of investigated wells, the time spent on research, the distribution of forces with means.

Effectiveness of the object (as measure of accomplishment (expedience)) is evaluated as correlation between functional systemic effect and labour effort for achieving this effect.

Economic efficiency is evaluated as correlation between "value" of functional systemic effect and value of "labour effort".

On condition that WS - functional systemic effect, RS - labour effort, the system effectiveness of the object is:

$$
\boldsymbol{E S}=\boldsymbol{W S} / \boldsymbol{R S} \text { (unit of effect / unit of labour effort) }
$$

Whereas CS (WS) - "value" of systemic effect (economic effect), CS (RS) - value of "labour effort", so economic efficiency of the object is equal to:

$$
E E=C S(W S) / C S(R S)
$$

"Labour effort" is equal to "labour content" of job for creation an effect:

$$
R S=\frac{W S}{a(1)}=N S \cdot T S
$$

Where a (1) - "productivity" of $1^{\text {st }}$ counting unit of (labour) forces (work teams) for creation of the effect, NS - quantity of labour "forces", TS - runtime of job.

"Value" of labour effort concludes:

- Amortization value of special source (CA);

- Value of cost source (CR);

- Salary payment for personnel (CP).

$$
C S(R S)=C A+C R+C P
$$

Let assume that we have identified $\mathrm{n}$ resources of drinking water with debit $\left(\mathrm{a}_{\mathrm{j}}, \mathrm{j}=\overline{1_{1} n}\right)$ and complex of analysis tool has standardized "productivity" for each source (because of its 
multiformity) $\left(b_{\mathrm{j}}, \mathrm{j}=\overline{1_{1} n}\right)$. When there are time outlays the $\tau_{\mathrm{j}}$ is analyzed, then the effect (amount of drinking water that was analyzed).

$$
\boldsymbol{W S}(X)=\sum_{j=1}^{n} \boldsymbol{w}_{\boldsymbol{j}}\left(\boldsymbol{x}_{\boldsymbol{j}}\right)=\sum_{j=1}^{n} \boldsymbol{a}_{\boldsymbol{j}}\left\{\mathbf{1}-\boldsymbol{e x p}\left(-\boldsymbol{b} x_{\boldsymbol{j}}\right)\right\}, \mathbf{j}=\overline{1_{1} n}
$$

$a_{j}-$ debit of drinking water resources;

$b_{j}$-standardized "productivity" of drinking water resources (drill holes);

$\boldsymbol{x}_{\boldsymbol{j}}$ - random variable that is bigger than $\ll 0 »(\mathrm{j}=1,2,3 \ldots)$;

$\mathrm{n}-$ amount of drinking water resources.

Therefore, labour effort of forces is calculated as:

$$
R S(X)=\sum_{j=1}^{n} \tau_{j} x_{j}
$$

$\tau_{\mathrm{j}}$ - time outlays.

Problem statement of scientific assignment is on set of distribution plans of forces and tools $\{X\}$, each of them $X=\left\langle x_{j}, j=\overline{1_{1} n}\right\rangle$ captures the limits (suitability criterion) WS $(\mathrm{X}) \geq \mathrm{WS}{ }^{\text {по }}{ }_{\gamma}$, at systems theory - the logical and methodological concept of objects research that are systems.

The technical and economic criterion is used in the calculations by the method of optimal cost and prospects for the application of expected results in future research. The connection between the criterion and the initial statistics is the optimal determination of the amount of funding in relation to the number of people living in rural areas and the use of decentralized water supply sources to implement an effective groundwater monitoring system.

To find out (create) the plan

$$
X^{\mathrm{o}}=\left\langle\boldsymbol{x}_{\boldsymbol{j}}^{\mathrm{o}}, \boldsymbol{j}=\overline{\mathbf{1}} \mathbf{n}\right\rangle \mathrm{C}\{\mathrm{X}\}
$$

$\{X\}$ - distribution of forces and tools;

which minimizes labour effort of system forces (optimality criteria)

$$
R S\left(X^{o}\right)=\min _{\{X\}} R S(X)=\sum_{j=1}^{n}\left(\tau_{j} x_{j}\right)
$$

and at the same time effectiveness of the system is at maximum:

$$
\operatorname{ES}\left(X^{o}\right)=W S\left(X^{o}\right) / R S\left(X^{o}\right)=W S^{n o \gamma} / \min _{\{x\}} R S(X)=\max _{\{x\}} E S(X)
$$


Optimal plan of force apportionment for solving the monitoring task is given by solution of the assignment.

\section{Results and discussion}

Research of water quality at rural areas is a complex supersystem, because it defines certain amount of conditions and elements that should show optimal effect while functioning.

The water supply supersystem is an optimal network of groundwater monitoring in rural settlements, which combines the most acceptable number of research specialists, terms (frequency) of monitoring, economic and logistical components of this event.

The term "supersystem" is introduced and used by the authors in the sense of "array of aquifers, a complex system of drinking water supply", as it refers to a set of measures aimed at creating a groundwater monitoring system in rural areas of the whole region - Kyiv region, with the prospect of application a similar supersystem for monitoring groundwater in Ukraine.

Presentation of the supersystem includes the creation of a database and maps, based on the obtained monitoring data during 3 years, the separation of zones with exceeding water quality indicators and the analysis of similar exceedances (natural or anthropogenic). Separation of zones with established anthropogenic pollution will allow to identify observation wells and to establish automatic monitoring points for groundwater monitoring, which would in real time demonstrate to the average citizen the quality of water in a particular area.

Given that at the legislative level, water quality must be regularly checked by legal entities, this requirement is not established and is not required for the obligations of individuals. It would be expedient to determine the type of water supply, if the decentralized water supply of a rural settlement is carried out at the expense of wells on the balance of the united territorial community, then the specific households that use this water are connected. If the residents of private houses use water from their own wells, it is advisable to study the quality of water from the wells of every second private household.

At Kyiv's region it is discovered the biggest amount of areas of groundwater sources in Ukraine. At numbers it is 135 areas, what is $45 \%$ of exploration of forecast resources of the region. There could be approximately maximum 300 areas (Statistic 2018).

The Instruction of invocation of Classification System of the Mineral Reserves and Resources of the State Fund of Subsurface Wealth to Assets of Drinking and Technical Underground Waters was ratify on $4^{\text {th }}$ of Feb 2000 by order №23 of State Committee of Ukraine on Reserves of Mineral Resources under the jurisdiction of Committee of Ukraine concerning to Geology and Subsurface Use. 
According to this document:

- Forecasting ground water resources are amounts of ground waters that are evaluated according to figures from geological study of subsurface resources, which are characterizing potential opportunities of its mining at specific location.

- Area of underground water deposits is the spatially confined section of underground water deposits, where the favorable conditions of getting underground water by separate extraction are.

- Water extraction is a building or facility for water intake from the waterbody.

Water extraction of underground waters could consist of one or group of space-saving installations for water extraction (drill holes, water wells, ground-water tappings).

Intense drop of the level of underground water has been observed at last 5 years. Due to that, it would be appropriate to aim at drill holes while making the calculations and to put in place 1 water extraction as 1 drill hole.

- Drill hole is the mining output; deep, narrow and round cross-section hole in ground coat, which was made by drilling tool (State Commission of Ukraine on mineral reserves 2000).

According to data from Central Administrative Authority of Statistics in Kyiv's region (data date $1^{\text {st }}$ of Jan 2019), the amount of population endowment of the region is 1767940 people (without including Kyiv city inhabitants). Urban population is 1097273 people, what is $62,1 \%$, and rural population is 670667 people (Statistic 2019).

Regarding to Kyiv's region Environmental Passport in 2019, the number of small towns is 30 and the quantity of villages is 1126 .

At the program "Drinking Water of Kyiv's Region on 2017-2020" there is information, that 30 small towns and 535 villages are provided by public drinking water supply. And $1126-535=591$ (52,5\% of total quantity) villages are using decentralized water-supply sources. In other words, more than half of village settlements and inhabitant of that areas are using water wells and drill holes for the purpose of drinking and sanitary-and-hygienic needs (Kyiv Regional Council 2017).

The calculations were made by the authors of the article according to the need to cover researches of drinking water quality at rural areas, taking into account that available resources are limited, both human and physical. In other words, it has been determined the need of water monitoring and what are the subjects of state water monitoring at the state level, but at the same time a system / plan, according to which this monitoring could actually be carried out, has not been approved. The scarcity of resources was determined by researchers by the lack of monitoring data on the underground water quality at rural territories, including the lack of data on official web resources and in the responses provided to requests sent to state bodies, defined at the legislative level as subjects carrying out state monitoring of waters. 
Data for calculations has been taken according to statistical data (Statistic, 2019) and information from The program "Drinking water of Kyiv region for 2017-2020". Also, it has been taken from opinion poll of rural population, State institution employees and own positions of authors that are based on their practical experience.

Average annual temperature of the air in 2017-2018 in Kyiv's region increased by $2,1{ }^{\circ} \mathrm{C}$ in comparison with standard average yearly temperature. So, it's safe to assume that water level in water wells revised down notably or even water has been disappeared from water wells. Subsequently we can assume that inhabitants are using drill holes. At around 352100 people live in 591 villages. Approximately 3 people live at one house, what means there are about 117367 houses. Not everyone is able to own drill hole for personal use. In sum nearly 2-3 families are using 1 drill hole. If 3 families are using 1 drill hole, then 117367 / $3=39122$ drill holes.

As the inspections of physical entities are not provided by current law in the field of ground water usage, so in the main only a few obey to the requisition of making laboratory researches of drinking water according to the requirements of State Sanitary Regulations and Rules "2.2.4-171-10" named "Hygienic Requirements to Quality of Water Intended for Human Consumption". And also, these entities are doing this on one's own initiative. Regarding to Water Code of Ukraine, extraction and/or usage of water in amount up to $5 \mathrm{~m}^{3}$ per day (except water that is used for producing (is a part of it) of drinks and prepacked drinking water) is not a special water use (extraction and usage of water is allowed without permission for special water use). According to the data of E-services Portal, Government Agency of Water Resources of Ukraine maintains a register of water users (legal entities), which are operating by right of permission for special water use. As at date of Apr 2020, 637 water users (enterprises are located at villages of Kyiv's region) are doing water extraction from 1348 drill holes. Laboratory researches of water should be done every quarter. This requirement is noted in conditions of permission for special water use. Unfortunately, it is also ignored by entities or is done in a "formal" way (what means it is done only at the papers). This is atrociously nuisance phenomenon, because enterprises and their employees are exposed to danger by themselves by using that water. And consumers are also exposed to danger, when enterprises are using this water for drinks and food production. Let us assume that it is possible to check quality of the water from drill holes of entities once a year. In this case drill holes owned by physical entities are taking into account while the calculations of complex system research (which has not been researched yet) are being done. So, there are 39122 drill holes at 591 villages, what means at one village there are $39122 / 591=66$ drill holes. And for work team of 2 people, it would be fixed 33 drill holes for each employee. Within a year it should be collected and researched 33 drill holes * 4 quarters $=132$ samples of water per person per year. Minimum national living wage as on 2020 is $4723 \mathrm{UAH}$. If water research of these resources is made every quarter, time investment of worker is 
4 months per year. Taking into account, costs for researches from point of sample collection to laboratory testing and processing of research results and reporting are taking out at the time of 1 month $* 4$ quarters $=4$ months per year. Amount of labour costs for one employee is $4723 * 4=$ 18892 UAH per year. For 1182 employees (2 workers at each of 591 villages) it would be $1182 *$ $18892=22330344 \mathrm{UAH}$, that is 22330,344 thousand UAH $(22,3$ million UAH). Transportation expenses per month are 591 villages * $3000 \mathrm{UAH}$ per month (fuel oil, rental lease and amortization of the transport $)=1773000 \mathrm{UAH}$ per month and per year it would be $1773000 * 4$ month $=$ 7092000 UAH (7,09 million UAH)

Costs of chemical reagent for 1 collected sample are approximately $500 \mathrm{UAH}$. That is to say, 39122 drill holes $* 4$ samples per year $=156488$ samples per year. So, the annual cost for reagent is 156488 samples per year $* 500$ UAH per sample $=78244000$ UAH per year (78,24 million UAH).

Amount of cost for one-time annual accuracy check of laboratory analysis of water from drill holes that are owned by legal entities is 1348 drill holes $* 4$ quarters $=5392$ samples; 5392 samples $* 500$ UAH per sample $=2696000 \mathrm{UAH}$ per year $(2,7$ million $\mathrm{UAH})$.

In conclusion of the previous information, there is a necessity to set up 1182 workplaces (for creation of a team of 2 researches for 591 villages) for establishing optimal system of underground water monitoring in rural areas of Kyiv's region. Therewith it is needed to make quarter researches of water quality from drill holes, which are owned by physical entities (39122 drill holes) and annual researches of water quality from drill holes of legal entities (1348 drill holes).

Total expenses:

- Water quality research of drill holes of physical entities

22330344 UAH (labour costs) + 7092000 UAH (transportation expenses) + 78244000 UAH $($ costs of chemical reagents $)=107666344 \mathrm{UAH}$ per year;

- Water quality research of drill holes of legal entities

2696000 UAH per year (costs of chemical reagents)

In total: 107666344 UAH per year +2696000 UAH per year $=110362344$ UAH per year $(110,36$ million UAH per year).

According to the formula 1, there is necessity to calculate correlation between "value" of functional systemic effect and value of "labour effort" for evaluation of the economic efficiency. But in this case "value" is not taken to the consideration for reasons beyond control. 


\section{Conclusions}

As eco-friendly environment (in this case because of safe drinking water from underground sources) and population healthcare could not potentially have a value, so we understand costs like a service that is connected with purchase of friendly environment and investments into health of population.

The final stage of calculations (that is the optimal plan) includes data of substantiating of the human needs and physical resources and also their rational distribution. As the other ways has not been defined and made public at the state level, the authors believe that the proposed plan can be taken into account by the subjects of state water monitoring and it is possible to develop a program for state water monitoring on its basis.

Based on data results we are able to create a map of groundwater quality monitoring, which is going to be updated every quoter of the year. So that the government could receive permanently updated data, what should help to find and prevent dangerous areas with inappropriate quality of the water and in perspective research resources of negative influence on water objects within region for slower evolution of environmental crisis of water resources in region. Furthermore, it is effectual to use such model in other regions of Ukraine.

\section{Conflict of interests}

The authors declare that they have no conflict of interest.

\section{References}

Abiriga, D.; Vestgarden, L. S.; Klempe, H. «Groundwater contamination from a municipal landfill: Effect of age, landfill closure, and season on groundwater chemistry». Sci. Total Environ., 2020, 737, Article 140307. doi:10.1016/j.scitotenv.2020.140307

Aleya, L.; Grisey, E.; Bourioug, M.; Bourgeade, P.; Bungau, S. G. «Proposed changes for postclosure monitoring of Etueffont landfill (France) from a 9-year survey». Sci. Total Environ., 2019, 656, 634-644. doi:10.1016/j.scitotenv.2018.11.406

Central Administrative Authority of Statistics in Kyiv's region. http://kyivobl.ukrstat.gov.ua/content/p.php3?c=115\&lang=1 (accessed Jan 1, 2019).

Di Guardo, A.; Volpi, E.; Finizio, A. «Analysis of large-scale monitoring data to identify spatial and temporal trend of risk for terbuthylazine and desethyl-terbuthylazine in surface water bodies of Po plain (Italy)». Sci. Total Environ., 2020, 740, Article 140121. doi:10.1016/j.scitotenv.2020.140121 
Hansen, B.; Thorling, L.; Kim, H.; Blicher-Mathiesen, G. «Long-term nitrate response in shallow groundwater to agricultural $\mathrm{N}$ regulations in Denmark». J. Environ. Manage., 2019, 240, 66-74. doi:10.1016/j.jenvman.2019.03.075

Instructions for the application of the Inventory Classification and mineral resources of the state subsoil fund to deposits of drinking and technical groundwater. Order of the State Commission of Ukraine on mineral reserves №23. https://zakon.rada.gov.ua/laws/show/z0109-00 (accessed Feb 4, 2000).

Jha, M. K.; Shekhar, A.; Jenifer, M. A. «Assessing groundwater quality for drinking water supply using hybrid fuzzy-GIS-based water quality index». Water Res., 2020, 179 Article 115867. https://doi.org/10.1016/j.watres.2020.115867

Lehmann, R.; Totsche, K. U. «Multi-directional flow dynamics shape groundwater quality in sloping bedrock strata». J. Hydrol., 2020, 580, Article 124291. doi:10.1016/j.jhydrol.2019.124291

Li, H.; Gu, J.; Hanif, A.; Dhanasekar, A.; Carlson, K. «Quantitative decision making for a groundwater monitoring and subsurface contamination early warning network». Sci. Total Environ., 2019, 683, 498-507. https://doi.org/10.1016/j.scitotenv.2019.05.121

Preziosi, E.; Frollini, E.; Zoppini, A. et al. «Disentangling natural and anthropogenic impacts on groundwater by hydrogeochemical, isotopic and microbiological data: Hints from a municipal solid waste landfill». Waste Manage., 2019, 84, 245-255. doi:10.1016/j.wasman.2018.12.005

Ravindra, K.; Mor, S. «Distribution and health risk assessment of arsenic and selected heavy metals in Groundwater of Chandigarh, India». Environ. Pollut., 2019, 250, 820-830 doi:10.1016/j.envpol.2019.03.080

Resolution of the Cabinet of the Ministry of Ukraine № 758 "Continuation of the Procedure for Water Monitoring". https://zakon.rada.gov.ua/laws/show/758-2018-п (accessed Sept 19, 2018).

Statistical Information of the State Research and Production Enterprise State Information Geological Fund of Ukraine Home Page. http://geoinf.kiev.ua/ (accessed Jan 21, 2018).

The program "Drinking water of Kyiv region for 2017-2020». https://docs.dtkt.ua/ru/download/pdf/1129.8069.1 (accessed May 19, 2017).

Water Framework Directive 2000/60/EC. https://ec.europa.eu/environment/water/waterframework/index_en.html (accessed Oct 23, 2000). 


\title{
ПРОБЛЕМНІ ПИТАННЯ ЗДІЙСНЕННЯ ЕКОЛОГІЧНОГО МОНІТОРИНГУ ЯКОСТІ ПІДЗЕМНИХ ВОД СІЛЬСЬКИХ НАСЕЛЕНИХ ПУНКТІВ КИЇВСЬКОї ОБЛАСТІ
}

\author{
${ }^{\prime *}$ B. А. Сердюк, ${ }^{1}$ B. I. Максін \\ ${ }^{1}$ Національний університет біоресурсів і природокористування України, Київ, 03041, Україна \\ * Автор для листування: serdiukvi@ukr.net
}

\section{Реферат}

Захист водних ресурсів являється пріоритетною ціллю планети, в тому числі й України. Враховуючи посилення екологічної кризи через глобальне потепління, моніторинг якості підземних вод та облік водних ресурсів потребує негайного удосконалення та запуску механізму в роботу, адже зволікання, котрі спостерігали ще 10-15 років тому показали, що людство не в змозі відкласти питання екологічної кризи до появи неспішних рішень чи наявності коштів, чи будь якого іншого сприятливого моменту. Екологічна криза вже масштабно розпочалася. Так в Україні, регіони, котрі були добре забезпечені водою почали страждати від засух та буревіїв. В сільського населення в криницях зникає, а місцями i зникла вода, не є виключенням і Київська область, одна з найбільш заселених областей України.

Постачання безпечної води для міст України постійно озвучувана в суспільстві тема, в той же час питання виживання сіл замовчується. Враховуючи нерівномірний розподіл водних ресурсів між міським та сільським населення вагоме значення має матеріальна складова цього питання, так як більш платоспроможним жителям мегаполісів постачають воду за десятки, а той сотні кілометрів від місця розташування міста, відповідно та територія, яка б сама мала користуватися цими ресурсами, як правило сільська - їх втрачає. Потрібно переглянути свої підходи до вирішення цієї проблеми, розпочати інтенсивно здійснювати моніторинг вод, виявляти і ліквідовувати причини забруднення тієї питної води, що ще залишилася. Необхідно цілеспрямовано створити групу дослідників і вже розпочати діяти. А самий масив підземних вод розглядати як складну систему (надсистему) забезпечення населення питною водою, 3 метою удосконалення діючої системи моніторингу. На законодавчому рівні є всі передумови для запровадження дослідження даної системи та зроблено перші кроки здійснення державного моніторингу, але, нажаль, цього недостатньо. Як показали математично обгрунтовані розрахунки, ціна питання проведення цієї роботи $\mathrm{i}$ задіяння людських сил не можуть бути вище вартості послуги безпечного довкілля й інвестиції в здоров'я сільського населення. Необхідно звернути увагу громадськості до проблеми погіршення та зникнення води у селах Київської області.

Ключові слова: водозабір; ділянка родовища підземних вод; екологічний моніторинг; масиви підземних вод; підземні води; прогнозні ресурси підземних вод. 